\title{
Między misją a profesjonalizmem - wybrane konteksty odpowiedzialności współczesnego nauczyciela
}

\section{Between Mission and Professionalism: Selected Contexts of Contemporary Teacher's Responsibility}

\begin{abstract}
ABSTRAKT
Artykuł przedstawia wybrane konteksty odpowiedzialności w pracy zawodowej nauczyciela we współczesnej rzeczywistości społeczno-edukacyjnej. Omawiana jest w nim sylwetka nauczyciela w kontekście nieustannych zmian w przestrzeni szkolnej i społecznej, a wraz z nimi oczekiwań wobec nauczycieli, ich kompetencji i rozwoju zawodowego. Autorka na podstawie wybranych ujęć teoretycznych ukazuje nauczyciela jako lidera społecznego, analizuje zawód nauczycielski i jego rozwój na przestrzeni lat, przedstawia etyczny wymiar jego pracy oraz zwiqzek między osobowościq i wartościami a oddziaływaniem wychowawczym w przestrzeni szkolnej. Celem tekstu jest ukazanie wielości i różnorodności ról społecznych, jakie podejmuje nauczyciel w prakłyce edukacyjnej i wychowawczej. W artykule został zaprezentowany przekrój różnych teorii przedstawiających wielowymiarowość sylwetki pedagoga, zarówno w wymiarze edukacyinym, jak również społecznym i kulturowym. Działania pedagogiczne podejmowane w kontekście szybkich przemian ekonomicznych, społeczno-kulturowych i technologicznych wymagaja bowiem ciagłego
\end{abstract}

SLOWA KLUCZOWE etyka pracy, lider społeczny, nauczyciel, misja, profesjonalizm, rozwój zawodowy, wartości, wychowanie

\section{KEYWORDS}

ethics of work, social leader, teacher, mission, professionalism, professional development, values, upbringing

SPI Vol. 23, 2020/4 ISSN 2450-5358 e-ISSN 2450-5366 DOI: 10.12775/SPI.2020.4.003 Nadestano: 30.06 .2020 Zaakceptowano: 19.10.2020 Artykuły i rozprawy 
poszerzania zakresu zadań pracy zawodowej. Bycie nauczycielem nie jest jedynie profesja, ale całożyciowa misja, która niesie za sobq duża odpowiedzialność za wychowanka oraz za sposób oddziaływania wychowawczego, zarówno podejmowanego intencjonalnie, jak również będqcego pochodnq osobowości nauczyciela.

\section{ABSTRACT}

The article presents selected contexts of responsibility of the teacher's professional work in contemporary socio-educational reality. The teacher's profile is discussed within the frame of the context of constant changes in the school and social space as well as expectations towards teachers, their competences and development. Based on selected theoretical approaches, author describes the teacher as a social leader, makes analysis of the teacher profession and its development over the years, the ethical dimension of the teacher's work and the connection between his personality and values and the educational impact in the school space. The goal of the text is to show the multiplicity and diversity of social roles that the teacher takes upon in educational and upbringing practice. The article presents a cross-section of various theories showing the multidimensionality of the pedagogue's profile in educational, as well as social and cultural dimensions. The pedagogical activities carried out in the world of fast economic, socio-cultural and technological changes require continuous expansion of the scope of their professional work. Being a teacher is not only a profession, but a lifelong mission, which carries a lot of responsibility for the pupils and educational impact, taken intentionally as well as being a derivative of the personality of the teacher.

\section{Wstęp}

Myślenie o nauczycielu od zawsze było zorientowane na poszukiwanie ideału lub wzorca, który cechowałby się zarówno rzetelnym wykształceniem, jak i moralną doskonałością. Nauczyciel we współczesnym świecie żyje w obliczu gwałtownej zmienności zdarzeń i niepewności edukacyjnego jutra. Coraz częściej stoi na „rozdrożu dróg”, niepewny wobec wielości wyborów, przy jednoczesnym braku jasnych wskazówek i drogowskazów dotyczących realizacji swojej roli. Wątpliwości dotyczące tego jak (dobrze) uczyć wydają się być zatem naturalne, a potrzeba wsparcia, ukierunkowania i dialogu - zrozumiała. 
Rola nauczyciela nie ogranicza się tylko do przekazywania wiedzy przedmiotowej, dominującym aspektem jego aktywności zawodowej są działania wychowawcze. Jak wskazuje Jolanta Szempruch, „[...] już nie przekaz wiedzy, ale uczenie umiejętności poruszania się w świecie wielości i sprzeczności informacyjnej oraz w świecie konfliktów wartości i interesów wyznacza sens istnienia współczesnej szkoły" (Szempruch 2000: 127). Na szeroki zakres odpowiedzialności zawodowej nauczyciela składają się różne elementy wielowymiarowego układu społeczno-kulturowego. W obliczu wielości zadań wciąż otwarta pozostaje kwestia funkcjonowania nauczyciela między misją a profesjonalizmem. W poniższym tekście zaprezentowane zostały wybrane ujęcia teoretyczne dotyczące przemiany roli zawodowej nauczyciela, jego odpowiedzialności za elementy rzeczywistości edukacyjno-wychowawczej oraz za osobiste wartości wpływające na realizację procesu edukacyjnego.

\section{Nauczyciel jako lider zmian społecznych}

Szybko zmieniająca się rzeczywistość wymusza transformację roli nauczyciela, by kształtować optymalny dla wymagań współczesnego świata proces wspierania rozwoju uczniów, ich twórczości, kreowania nowych idei i celów życiowych. Współczesny nauczyciel, poza rolą edukatora podsiadającego wiedzę przedmiotową, powinien pełnić również rolę lidera - osoby, która zaangażowaniem w życie społeczne rozbudza świadomość swoich uczniów, tym samym zachęcając ich do aktywnego działania i podejmowania wyzwań natury społecznej. Bycie liderem społecznym jest nie tylko nowym elementem działalności szkolnej nauczyciela, ale także nową rolą społeczną. Przygotowanie nauczyciela do pełnienia funkcji działacza społecznego jest procesem niełatwym, bowiem uczenie się funkcji społecznych oraz realizowanie ich na wysokim poziomie jest uwarunkowane splotem różnych czynników osobowościowych oraz społeczno-ekonomicznych. Nauczyciel powinien być świadomy, że pracując dla społeczeństwa i jego przyszłości jest nie tylko - jak się uważa - odbiciem cech społeczeństwa, w którym żyje, i „efektem” społecznych doświadczeń, ale również, a może przede wszystkim, znaczącym podmiotem, mającym realny wpływ na budowanie przyszłości (Łukasik 2008: 320). 
Szkoła jako miejsce edukacji jest wpisana w układ społeczny, powinna być zatem miejscem otwartym na społeczność lokalną, problemy środowiska, w którym można się spotkać i współdziałać. Nauczyciel jako podmiot funkcjonowania szkoły i uczestnik jej życia tworzy w niej atmosferę i jest budowniczym relacji międzyludzkich. Współczesna szkoła powinna być miejscem „stawania się”, dialogu i partnerstwa między uczniem, nauczycielem i rodzicem. Powinny w niej dominować takie wartości jak otwartość, szacunek, poszukiwanie kompromisu, co więcej powinna ona również rozwijać społeczną i obywatelską postawę, kształtować „człowieka pogranicza”. To dlatego proces wychowania i kształcenia szkolnego jest nieoceniony w procesie budowania świadomości kulturowej. Szkoła powinna być przestrzenią spotkania drugiego człowieka, w związku z tym wyłaniają się dla niej specyficzne zadania: budowanie więzi z najbliższym środowiskiem, kształtowanie społecznych postaw, aktywizacja uczniów i ich rodziców. Sposobem aktywizacji i wyzwalania sił społecznych, o których pisała Helena Radlińska, jest „przodownictwo kulturalne", czyli metoda stymulacji, dynamizowania, wspomagania aktywności kulturalnej. Zatem nauczyciel, lider-animator - to osoba, która jest aktywna w środowisku lokalnym, potrafi rozpoznać jego możliwości, potrzeby i aspiracje, będąc wspomagającą, inspirującą i otwartą na propozycje działań, a jednocześnie kształtującą umiejętności i wskazującą kierunek rozwoju społeczności lokalnej (Sass 2011: 251-252).

To, czy rola lidera społecznego będzie efektywnie i w pełni przez nauczyciela realizowana, zależy od różnych czynników wewnętrznych i zewnętrznych. Do czynników wewnętrznych można zaliczyć wiedzę i umiejętności nauczyciela zdobyte podczas procesu kształcenia na różnych poziomach, bogactwo doświadczenia zawodowego i życiowego, kompetencje, a także właściwości umysłu i cechy osobowości. Zdolności, jakie powinien posiadać nauczyciel-lider, to przede wszystkim zdolność refleksyjnego, elastycznego myślenia i działania. Czynniki zewnętrzne to między innymi środowisko, w jakim żyje i pracuje nauczyciel: wieś, miasto, środowisko lokalne, sytuacja społeczna, polityczna czy ekonomiczna. Rola nauczyciela-lidera wykracza poza typową działalność szkolną, sprowadza się do podejmowania działań i inicjatyw pozaszkolnych oraz pracy opartej na mentorstwie. Zbigniew Kwieciński twierdzi, że współczesny pedagog powinien 
być mądry, kompetentny, wrażliwy, krytyczny i uważny, winien umieć być doradcą, tłumaczem i współuczestnikiem codziennych problemów, jakie dotykają uczniów, ale jednocześnie powinien odkrywać przed wychowankiem nowe znaczenia i wartości, cierpliwie słuchać i przewodzić, czerpiąc wiedzę i próbując znajdować odpowiedzi na podstawie osobistych doświadczeń (Dyrda 2011: 158-159, 162, 167-169). To właśnie „przewodzenie” uczniowi sprawia, że nauczyciel z niepodważalnego autorytetu staje się liderem, który animuje środowisko szkoły, a także środowisko lokalne (Sass 2011: 251-252). Odpowiedzialność społeczna lidera jest związana z byciem odpowiedzialnym za działania wobec innych osób - uczniów, rodziców, nauczycieli, zbiorowości lokalnej, co wymaga od nauczyciela refleksyjności, czyli odnoszenia swoich działań do etycznych i politycznych kontekstów oraz krytycyzmu wobec zakładanych efektów oddziaływań wychowawczych (Olejniczak 2010: 54-56).

\section{Przemiany roli zawodowej nauczyciela}

Wraz ze zmieniającą się rzeczywistością edukacyjną pojawiają się coraz to nowe oczekiwania wobec nauczyciela. Cele edukacji stanowią punkt odniesienia do projektowania jego działań, a co za tym idzie, wyznaczają konieczność ciągłej zmiany roli zawodowej nauczyciela. Określenie „nauczyciel” od zawsze było zarezerwowane dla osoby, która wypełniała funkcję edukacyjną, mimo że na przestrzeni lat termin ten miał różne znaczenia.

W czasach starożytnych do bycia nauczycielem wystarczająca była znajomość treści stanowiących przedmiot nauczania, a umiejętność przekazu wiedzy uznawano za sztukę, dar, a nie rezultat wyuczenia. Wraz z rozwojem życia intelektualnego i powstawaniem uniwersytetów zawód nauczyciela zyskał inną rangę, jednak nie istniała jeszcze dydaktyka jako teoria nauczania, w związku z czym nie następowały wielkie zmiany w obszarze sprawności przekazywania wiedzy. Nastąpiło to dopiero w XVII wieku wraz ze stworzeniem przez Jana Amosa Komeńskiego nowożytnych podstaw dydaktyki. W Polsce przełomowym wydarzeniem było powstanie Komisji Edukacji Narodowej w 1773 roku. Utworzyła ona odrębny „stan nauczycielski”, a kształcenie nauczycieli zaczęto organizować przy Szkołach Głównych w Akademii Krakowskiej i Wileńskiej. Kadry do szkół 
parafialnych z kolei kształciły seminaria nauczycielskie. W XIX wieku obok kształcenia rzeczowego nastąpiło wzmocnienie potrzeby kształcenia nauczycieli w obszarze psychopedagogicznym. Powstała również koncepcja kształcenia na poziomie uniwersyteckim, która urzeczywistniła się głównie dzięki Janowi Fryderykowi Herbartowi. Założył on i prowadził na uniwersytecie w Królewcu seminarium pedagogiczne dedykowane nauczycielom szkół średnich. Wiek XX nazywany jest wiekiem „odkrycia dziecka”, a zatem również „odkryciem nauczyciela”. Rozwój psychologii przyczynił się do poszerzenia wiedzy o osobowości nauczyciela, jego talencie i zdolnościach wychowawczych. Wtedy zaczęto także akcentować ideę kształcenia wielostronnego, uwzględniającą wielość różnorodnych czynników przesądzających o rezultatach kształcenia, potrzebę aktywności poznawczych, uczuciowo-emocjonalnych i działaniowych oraz formy organizacyjne: jednostkowe, zbiorowe, grupowe, które powinny być wykorzystywane przez nauczyciela w procesie kształcenia (Kwiatkowska 2008: 24-27).

Wraz z dalszym postępem cywilizacji, rozwojem nauki i technologii zwiększały się wymagania wobec nauczyciela. Także dziś kwalifikacje nauczycielskie ulegają wciąż rozszerzaniu, wyznaczane są także nowe zadania zawodowe. W takiej sytuacji istnieje konieczność edukacji ustawicznej nauczyciela, która oprócz przekazywania wiedzy uczy jej samodzielnego stosowania i wytwarzania. Nowe wymagania sprawiają, że nauczyciel poza funkcją poznawczą, sprawnościową i opiekuńczą pełni wobec dziecka również funkcję egzystencjalną, czyli uczy je jak tworzyć sens życia, jak radzić sobie z problemami, jak żyć, uczyć się i oceniać efekty własnej pracy. By pełnić tę funkcję efektywnie, potrzebna jest edukacja, która przygotuje uczniów wchodzących w dorosłość do dokonywania wyborów bez stosowania dychotomicznego podziału na dobro i zło (Kwiatkowska 2008: 24-27).

Analizując przemiany roli zawodowej, warto się przyjrzeć ujęciom osoby nauczyciela. Henryka Kwiatkowska wyróżniła następujące ujęcia: psychologiczne (osobowościowe), technologiczne, humanistyczne, socjologiczne, pedagogiki krytycznej (Kwiatkowska 2008: 24-27). Ujęcie psychologiczne zakłada, że nauczyciel jest strukturą idealnych cech. Kryterium decydujące o tym, czy można kogoś uznać za dobrego nauczyciela, stanowi tutaj jego osobowość. W nauczycielu chce się widzieć „Zwierciadło wszelkich cnót”, a myślenie o nim jako 
o doskonałości przetrwało do dzisiaj. Najczęstszymi słowami, jakich w tym kontekście się używa w odniesieniu do nauczyciela, są: wzór, ideał, powołanie, misja, talent, instynkt, służba dziecku.

Jan Władysław Dawid był jednym z przedstawicieli „osobowościowego" ujęcia nauczyciela. Uważał, że wychowanie jest naturalnym procesem, a wychowawca jest jego kierowniczą siłą, jednak o tej mocy decyduje to, kim jest nauczyciel i jakim chciałby być. Podkreślał również znaczenie uczuciowej bliskości i „duchowego życia”, czemu winna towarzyszyć zdolność komunikowania własnych stanów duchowych oraz odbioru cudzych. Oprócz tego nauczyciel winien się charakteryzować następującymi cechami: moralną odwagą, wewnętrzną prawdziwością, poczuciem odpowiedzialności, dążeniem do doskonałości, obowiązkowością, gotowością do walki z trudnościami i do ponoszenia ofiar, uznawaniem prawa do indywidualnej aktywności. Dawid ten wizerunek określił kategorią „miłości dusz”, która jest istotą nauczycielstwa (Kwiatkowska 2008: 30).

Zygmunt Mysłakowski i Stefan Szuman - kolejni przedstawiciele osobowościowego ujęcia nauczyciela - używali kategorii „talentu”. Według Mysłakowskiego talent „[... ] jest wrodzoną dyspozycją psychofizyczną, dzięki której osobnik pewne szczególne typy działalności [...] uprawiać może bardziej wydajnie" (Kwiatkowska 2008: 30). Zawiera się w tej definicji zastrzeżenie, że o talencie świadczy realizacja posiadanych predyspozycji, a nie sam fakt ich posiadania. $\mathrm{Za}$ istotę nauczycielstwa uznawał on kontaktowość, czyli efektywne porozumiewanie się dwóch osób, zakładające istnienie między nimi oddźwięku psychicznego, wspólnoty znaczeń, odczuć i reakcji. Dla Szumana talent to zespół pewnych zdolności, a zdolność to posiadanie pewnej cechy psychicznej, która ułatwia wykonywanie określonych czynności na wysokim poziomie. Rozumiał talent pedagogiczny nie jako wrodzoną cechę, ale jako osobowość nauczyciela, która nie musi być wcale podobna do innych nauczycieli, bowiem każdy z nich jest twórcą swojego własnego talentu. Szuman wyróżnił dwie kategorie stanowiące istotę nauczycielstwa: bogactwo osobowości oraz umiejętność dysponowania tym bogactwem. Poza tym ważna była dla niego harmonia i integralność dojrzałego charakteru, walorów etycznych, rozległej wiedzy i „pięknej duszy” (Kwiatkowska 2008: 31).

Stefan Baley za istotę nauczycielstwa uważał „zdolność wychowawczą", którą ujmował jako zbiór cech niezbędnych do realizacji 
działania wychowawczego. Ten swoisty zbiór zawiera: powinowactwo duchowe $\mathrm{z}$ wychowankiem, przychylność, cierpliwość, entuzjazm, rozumienie psychiki dziecka, nastawienie na zajmowanie się nim, zdolności artystyczne. Ten, kto posiadał te cechy w ponadprzeciętnym stopniu, był uznawany za „wychowawcę integralnego”. Tym, co w osobowościowym ujęciu sylwetki nauczyciela jest ważne także dzisiaj, to założenie, że opis nauczyciela zawsze zawiera zbiór idealnych cech, które powinien on posiadać (Kwiatkowska 2008: 33).

Ujęcie technologiczne uznaje za dominujące w osobie nauczyciela jego kwalifikacje zawodowe, a główną kategorią opisu są kompetencje lub określone czynności zawodowe. Kompetencja to „[...] zdolność i gotowość podmiotu do wykonania zadań na oczekiwanym poziomie" (Kwiatkowska 2008: 35), która powstaje w efekcie integracji wiedzy, wielu umiejętności oraz sprawności w dokonywaniu oceny. W ujęciu technologicznym warto wymienić dziewięć typów zachowań mających miejsce w interakcji nauczyciel-uczeń, które wyodrębnił Ned A. Flanders. Wśród tych odnoszących się do nauczyciela należy wymienić: akceptację stanów emocjonalnych uczniów, nagradzanie, wykorzystywanie pomysłów uczniów, zadawanie pytań, nauczanie, udzielanie wskazówek, wyrażanie krytycznych uwag. Natomiast do typów zachowań odnoszących się do uczniów należy zaliczyć: reagowanie na zadawane pytania, wyrażanie własnej inicjatywy, sposób reakcji na moment ciszy lub zamieszanie w klasie. Raymond Adams z kolei ujął podstawowe czynności nauczyciela w postaci wyrażeń czasownikowych: pyta, poleca, informuje, nagradza, ocenia, wyjaśnia (Kwiatkowska 2008: 35).

Ujęcie humanistyczne podkreśla prymat indywidualności nauczyciela na bazie trzech głównych założeń nurtu humanistycznego pedagogiki: (1) człowiek jest autonomiczną, niepowtarzalną całością, która realizuje się w kontakcie z innym człowiekiem; (2) wiedza wyrasta $\mathrm{z}$ osobistego doświadczenia jednostki, ma charakter podmiotowy, indywidualny i najbardziej wpływa na działanie nauczyciela; (3) kształcenie jest formą komunikacji interpersonalnej i opiera się na wzajemnym rozumieniu podmiotów edukacji. W ujęciu humanistycznym „dobry nauczyciel” oznacza życzliwego ludziom człowieka o niepowtarzalnej osobowości, kultywującego w sobie te elementy, które sprawiają, że jest osobą znaczącą, ważną i niestandardową dla ucznia. Ujęcie socjologiczne do określenia osoby nauczyciela używa 
pojęcia roli zawodowej/społecznej. Rola społeczna „[...] zakłada zbiór norm i wartości związanych z określoną pozycją społeczną - przypisanych do tej pozycji i wymaganych od każdego, kto tę pozycję zajmuje" (Kwiatkowska 2008: 37). Zatem nauczyciel utożsamiający się z rolą społeczną działa zgodnie z kanonem oczekiwań społecznych, które precyzyjnie regulują jego zachowania. Przyjmuje on normatywny przepis roli, a adaptacja tych norm i ich respektowanie sprawia, że jednostka ma szansę być zaakceptowana w społeczeństwie i może bezpiecznie funkcjonować. Ujęcie pedagogiki krytycznej zakłada, że nauczyciel jest transformatywnym intelektualistą. Transformatywność w tym ujęciu to „[...] aktywność nauczyciela na rzecz dokonywania zmian w edukacji, a także w środowisku społecznym, poprzez wyzwalanie się z zastanych ograniczeń i wkraczanie na drogę urzeczywistniania polityki oporu" (Kwiatkowska 2008: 39). Nauczyciel jako transformatywny intelektualista jest aktywnym uczestnikiem procesu edukacyjnego, działa na rzecz demokracji, a jego nadrzędnym celem jest nauczanie myślenia krytycznego, kształtowanie własnych niezależnych poglądów i budowanie w uczniu świadomości, że to on najbardziej się liczy w procesie edukacji (Kwiatkowska 2008: 28-40).

Podobnie jak wizerunki osobowe nauczyciela w ujęciu teoretycznym, zmieniały się również funkcje zawodowe nauczyciela. Kwiatkowska wymienia tendencje zauważalne w ewolucji funkcji zawodowych nauczyciela, które mają duże znaczenie dla współczesnej edukacji zmierzającej do kształcenia uczniów do życia w społeczeństwie wiedzy nacechowanym dynamicznymi zmianami i wzrastającym ryzykiem (Kwiatkowska 2008: 40-45). Ewolucja funkcji zawodowych nauczyciela jest związana $z$ następującymi zmianami w rzeczywistości społeczno-kulturowej: od poczucia bezpieczeństwa do poczucia zagrożenia; od odpowiedzialności grupowej (instytucjonalnej) do personalnej (indywidualnej); od przystosowania do rzeczywistości do jej przekształcania; od pracy z dominacją czynności powtarzalnych do pracy z dominacją czynności twórczych; od dominacji techniczności do wzrostu intelektualności; od kształtowania życia według tradycji do tworzenia jego własnej koncepcji. Pierwszą z tendencji zmian zawodowych funkcji nauczyciela jest zmiana w podejściu do transmisji wiedzy - od jej przekazywania do uczenia samodzielności w jej zdobywaniu. Dotychczasowe systemy edukacyjne skupiały się raczej na przekazywaniu wiedzy o faktach, niż na 
sposobach ich odkrywania. W dzisiejszych czasach relacja między wiedzą a metodami jej pozyskiwania powinna zostać odwrócona ze względu na fakt, że żyjemy w świecie znaczonym nieustannym przyrostem informacji. Aby posiadana wiedza była wiarygodna, aby czynić z niej użytek i by miała ona wpływ na zachowanie, jednostka musi mieć do tej wiedzy osobisty stosunek. Ważniejsza zatem, z punktu widzenia pełnienia funkcji nauczyciela, okazuje się organizacja procesu edukacyjnego, uczenie wartościowania oraz odnajdywania sensu w świecie opozycyjnych wartości, nie zaś sam sposób przekazywania wiedzy czy wartości. Drugą tendencją jest przechodzenie od sterowania rozwojem do inspirowania rozwoju. Wymaga to od nauczyciela działań refleksyjnych, umiejętności prowadzenia dialogu i poszukiwania kompromisu, namysłu nad swoimi decyzjami, odejścia od postawy dyktatu na rzecz porozumienia i wzmacniania indywidualności wychowanka. Trzecia tendencja to zmiana od prostego przekazu wiedzy do zaproszenia do wejścia w jej uniwersum. Działanie edukacyjne w tym przypadku nie polega na prostej transmisji wiedzy, lecz raczej na zaawansowanej aktywności myślowej, jaką jest poszukiwanie indywidualnych znaczeń wiedzy dla jednostki. Realizacja tej tendencji oznacza wyposażenie ucznia $\mathrm{w}$ umiejętności myślenia problemowego i rozwiązywania problemów, a dalej - opanowanie przez niego procedury poznania naukowego. Czwartą z tendencji jest zmiana od funkcji przekazu wiedzy do wprowadzania ładu w informacyjnym gąszczu. Szkoła w dzisiejszych czasach powinna przygotowywać do radzenia sobie z nadmiarem informacji. Współczesny pluralistyczny świat, w którym stykają się różne systemy wartości, wymaga umiejętności integrowania wiedzy. Aby jednak radzić sobie z tym wyzwaniem, potrzeba nie tyle pragmatycznych, ile intelektualnych umiejętności. Piąta tendencja zauważalna wśród zmian funkcji zawodowych nauczyciela związana jest $\mathrm{z}$ ustępowaniem dominacji intelektu na rzecz równowagi świata myśli i uczuć. W związku z tym istnieje potrzeba wzmacniania sfery uczuciowej i etyczno-moralnych kwalifikacji nauczyciela, by mógł on oferować uczniowi nie tylko wsparcie poznawcze: wiedzę, rozumienie, lecz także egzystencjalne wzmocnienie, pomoc. Szóstą tendencją jest przejście od alternatywy do dialogu. Alternatywa ogranicza możliwość wyboru, jest wartością opozycyjną, przeciwstawną, która coś nakazuje lub od czegoś odwodzi. Dialog z kolei jest dynamiczny, niedookreślony, sprawdza się 
w sytuacjach niestandardowych. Praca nauczyciela powinna zatem się kierować logiką dialogu, kontaktu i porozumienia z uczniami. Umiejętność dialogu i osiągania kompromisu to niezbędne sprawności, w które powinien być wyposażony nauczyciel. Powinien on również potrafić wyposażać w te umiejętności swoich wychowanków (Kwiatkowska 2008: 40-45).

Aby nauczyciel mógł sprostać wymaganiom współczesności, konieczna jest zmiana rozumienia roli zawodowej nauczyciela. Zmiana ta musi dokonać się na kilku płaszczyznach, przede wszystkim na polu myślenia i działania nauczyciela. Powinien on przejść od postrzegania siebie jako osoby, która pełni określoną rolę zawodową, do postrzegania siebie jako autonomicznego podmiotu, w którym nauczycielstwo stanowi integralną część całości. Innymi słowy chodzi o przejście od bycia $\mathrm{w}$ roli i spełniania zewnętrznie narzuconych wymagan do bycia sobą i nauczycielem jako jedności. Ten integralny rodzaj bycia powoduje, że nauczyciel potrafi łączyć zadania zawodowe i zobowiązania moralne wynikające z poczucia własnej tożsamości zawodowej i oczekiwań stawianych mu przez innych (Kowal 2004: 80).

\section{Etyczny wymiar pracy nauczyciela}

Odpowiedzialność jako kategoria moralna i wartość jest szczególnie ważna w zawodzie nauczyciela. Odpowiedzialność to „[...] specyficzne zobowiązanie wobec siebie i innych, określające postępowanie nauczyciela, stanowiące rezultat kierowania przez niego własnym działaniem" (Szempruch 2013: 263). Może to być odpowiedzialność za siebie samego (kierowanie własnym rozwojem) lub za kogoś innego - uczniów. Jest ona wynikiem dojrzałości moralnej, życzliwości, chęci odniesienia sukcesu oraz wymagań stawianych przez otoczenie. Odpowiedzialność w działalności nauczyciela dochodzi do głosu w czterech wymiarach: do ucznia, do siebie i swojego zawodu, do innego nauczyciela, do rodziców i społeczeństwa. Istotą i warunkami odpowiedzialności osoby nauczyciela są: wolność myślenia i czynu, system wartości, sumienie, aktywność i działanie oraz ponoszenie za nie konsekwencji, racjonalność (Szempruch 2013: 263, 270).

Janusz Homplewicz w kontekście oceny działań edukacyjnych wyróżnia trzy rodzaje odpowiedzialności nauczyciela: prawną, pedagogiczną i etyczną. $Z$ prawnego punktu widzenia chodzi 
o przestrzeganie obowiązujących przepisów podczas wypełniania obowiązków zawodowych. Praca pedagogiczna w tym kontekście jest sformułowana jako układ obowiązków i środków prawnych, w tym sankcji. Aby odpowiedzialność prawna za nienależyte wykonywanie obowiązków mogła zaistnieć, muszą zostać spełnione trzy warunki: ustalenie obowiązków, co będzie podstawą prawną odpowiedzialności; określenie konsekwencji za nienależyte wykonywanie obowiązków; stwierdzenie nienależytego wykonywania obowiązku i wydanie orzeczenia, decyzji lub wyroku. Częściej jednak niż z odpowiedzialnością prawną nauczyciel spotyka się z odpowiedzialnością pedagogiczną. W tym przypadku chodzi o nadzór pedagogiczny, który kontroluje zgodność działań nauczyciela z obowiązującymi przepisami oraz ich skuteczność i celowość. Kontrole te, w formie wizytacji czy hospitacji, mają na celu doskonalenie pracy pedagogicznej nauczycieli i instytucji szkolnej w ogóle. Można z nich wyciągać konsekwencje lub wydawać opinie, zalecenia lub polecenia. Ważną, jeśli nie najważniejszą, w kontekście wychowania jest odpowiedzialność etyczna. Wyraża się ona w postawie nauczyciela realizującego potrzeby dziecka, dbającego o jego dobro i rozwój. Istotna jest również postawa etyczna, poczuwanie się do odpowiedzialności, motywacja do pracy, stopień dojrzałości oraz prezentowane i realizowane przez nauczyciela wartości. Kwestia etycznej odpowiedzialności nie jest tylko sprawą sumienia nauczyciela, ale także kwestią profesjonalizmu w wykonywanym zawodzie (Homplewicz 1996: 186-188).

Zarówno poczucie misji, jak i chęć bycia profesjonalistą w zawodzie sprawiają, że etyka zawodu nauczyciela odgrywa bardzo ważną rolę w jego pracy. Przestrzeganie kodeksu etycznego jest szczególnie znaczące dla budowania prestiżu profesji nauczyciela. Jej główne wyznaczniki to między innymi nienaganna postawa moralna, wysoka kultura osobista, odpowiedzialność, wrażliwość, samokrytycyzm oraz uczciwość. Dobry nauczyciel-wychowawca powinien mieć „sztywny kręgosłup moralny" oraz przestrzegać zasad etycznych, mimo trudności i stresu, jakie są obecne podczas wypełniania obowiązków względem uczniów, rodziców i współpracowników (Janus 2012: 37). Znaczenie ma jednak nie tylko postawa nauczyciela, ale szereg innych elementów, które można określić jako moralne i etyczne lub niemoralne i nieetyczne. Warto zaznaczyć, że w zasadzie nie można mówić o nieetycznym lub niemoralnym wychowaniu, bowiem 
wtedy nie sposób mówić o postawie wychowawczej w ogóle. Moralna i etyczna charakterystyka działalności wychowawczej jest jej warunkiem i istotą jednocześnie. Zatem etyczne znaczenie ma nie tylko stosunek nauczyciela do ucznia, ale również treści programowe nauczania, czyli to, jakie umiejętności i wartości przekazuje i utrwala wychowawca (Homplewicz 1996: 21-23). Przy tworzeniu programów powinno się pamiętać o rozwoju intelektualnym i zawodowym, ale przede wszystkim o tych wartościach, które mają wpływ na rozwój moralny, kształtowanie postaw i ideałów życiowych. Kolejnym ważnym elementem obok programu nauczania są umiejętności samego nauczyciela. Umiejętności zawodowe wymagane do realizacji i przekazu wartości mają znaczenie etyczne, bowiem są niezbędne, by właściwie wykonywać zawód i być profesjonalnym nauczycielem. Nader istotnym wymogiem etycznym jest również poszanowanie godności wychowanka. Jest to podstawowy warunek i wartość wychowania. Nie ma zatem w działaniu pedagogicznym miejsca na agresję, presję, przymus, nadużywanie siły i władzy czy narzucanie i nacisk ze strony nauczyciela. $W$ procesach edukacyjnych należy wychodzić naprzeciw potrzebom wychowanka, rozumieć i pomagać w rozwoju - prowadzi to do kształtowania samodzielnej i dojrzałej jednostki (Homplewicz 1996: 21-23).

Najważniejszym celem w pracy nauczyciela jest wychowanie człowieka mądrego, dysponującego wiedzą etyczną i umiejętnościami, które pozwolą dokonywać mu właściwych wyborów, a następnie podejmować decyzje, za które będzie on ponosił odpowiedzialność moralną. Aby jednak pomóc uczniowi stać się człowiekiem mądrym, nauczyciel sam musi takim być. Do etycznych kompetencji nauczyciela należą niewątpliwie takie elementy jak: posiadanie podstaw wiedzy etycznej, umiejętności, które ułatwiają rozstrzyganie konfliktów moralnych, a także rozeznanie i rozumienie najważniejszych dylematów etycznych współczesnego świata (Szewczyk 2013: 9-10). Już sam wybór nauczycielstwa jako zawodu jest decyzją moralną, powinien on być zatem wolny, świadomy, racjonalny, odpowiedzialny i nastawiony na urzeczywistnianie wartości etycznych. Co więcej, wybór ten stanowi zarazem wybór wartości autotelicznej, której realizowanie jest jednocześnie etycznym obowiązkiem oraz powinnością moralną nauczyciela (Szewczyk 2013: 39). 
Janusz Homplewicz podaje kilka ogólnych zasad etyki pedagogicznej, którymi winien się kierować każdy nauczyciel: zasada prawdy, dobra dziecka, przykładu, projekcji pedagogicznej, więzi emocjonalnej, poszanowania osobowości, profesjonalizmu (Homplewicz 1996: 73-74). Zasada prawdy zakłada, że postawa życiowa nauczyciela oraz to, co on mówi i czyni, jest rozeznaniem, dążeniem i wyrażaniem prawdy. W działaniu w imię prawdy wyraża się etyczna postawa nauczyciela, dlatego jego zachowanie i osobowość powinny $\mathrm{z}$ całą mocą tę prawdę akcentować. Zasada dobra dziecka to założenie, że dziecko, jego dobro, bezpieczeństwo i rozwój stanowią główny motyw oraz wskazówki do działania. Ujawnia się tutaj wymóg poczucia odpowiedzialności za dziecko, czyli zabezpieczenie, rozumienie i realizacja jego dobra. Zasada przykładu wyraża przekonanie, że nauczyciel stanowi przykład, z którego czerpią uczniowie jako źródła wartości, ideałów, treści, postaw i umiejętności. To, co posiada lub prezentuje wychowawca, staje się również treścią przekazu, która kształtuje osobowość i światopogląd wychowanka. Zasada projekcji pedagogicznej zakłada, że nauczyciel wie jak mówić, by wychowanek zrozumiał i jak się zachowywać, by zdobyć jego zaufanie i otwartość. Tylko wtedy wpływ wychowawczy może naprawdę zaistnieć, gdyż nauczyciel pojmuje co i jak uczeń widzi oraz czuje. Zasada więzi emocjonalnej to umiejętność nawiązywania i utrzymywania osobistego kontaktu z wychowankiem. Od poziomu tej kontaktowości również zależy efektywność procesów wychowania. Zasada poszanowania osobowości zakłada, że nauczyciel dostrzega i docenia niepowtarzalność osobowości ucznia. Janusz Korczak mówił o „autorytecie dziecka”, o istocie, której należy się szacunek i ochrona godności osobistej. Zasada profesjonalizmu wymaga natomiast od nauczyciela by był kompetentny i dojrzały, posiadał zawodowe kwalifikacje i umiejętności, które pomogą w skutecznym działaniu pedagogicznym (Homplewicz 1996: 73-74).

\section{Internalizacja wartości a wychowanie szkolne}

Wychowanie jako realizacja pewnych wartości obejmuje swym zasięgiem wiele różnorodnych aspektów rozwoju człowieka. Wartości te można przyporządkować do dwóch podstawowych grup. Pierwsza $\mathrm{z}$ nich to dziedzina etyczna wartości wewnętrznych - dotyczy ona 
człowieka, jego właściwości, cech, rozwoju. W związku z tym grupują się one w trzy kategorie: wartości związane $\mathrm{z}$ osobowością jednostki, z jej wszechstronnym rozwojem oraz postawą i czynami. Druga dziedzina wartości etycznych to dziedzina społeczna, dotycząca współżycia $\mathrm{z}$ innymi ludźmi. Trzy kategorie wartości społecznych to: wartości związane z życiem rodzinnym i formami samorealizacji, współpraca z innymi ludźmi w różnych środowiskach i wspólnotach, umiejętność pracy i zawodu (Homplewicz 1996: 146-147, 149). Przykładowo, do wewnętrznych wartości wychowania można zaliczyć: miłość, dobroć, życzliwość, serdeczność, uczuciowość, wdzięczność, ufność, otwartość, zaufanie, wierność, prawość, męstwo, odwagę, wytrwałość, mądrość, roztropność, poczucie odpowiedzialności, sumienność, wspaniałomyślność, hojność, cierpliwość, bezinteresowność, dyskrecję, pokorę, uczciwość. Z kolei wartości społeczne wychowania obejmą: nauczanie i kształcenie, fachowość, talent i takt pedagogiczny, przykład, kontaktowość, przyjaźń, braterstwo, tolerancję, pomoc, służbę, opiekę, pracowitość i wiele więcej. Wychowanie zaczyna się od wyboru ustalonych wartości, które z kolei określają cele i zadania dla wychowania. Wartości, które są urzeczywistniane w procesie wychowania, a w związku z tym także zadań może być jednak o wiele więcej (Homplewicz 1996: 146-147, 149).

W Polsce wraz z przekształceniami ustrojowymi zmieniły się priorytety edukacyjne, co spowodowało konieczność przekształcenia celów opartych na wartościach wypływających z narzuconej przez system polityczny ideologii w cele nawiązujące do wartości humanistycznych. Podstawę określania celów edukacji stanowi zbiór uniwersalnych wartości. Eksponowanie danego systemu wartości związane jest $\mathrm{z}$ kształtowaniem odpowiednich postaw, a co za tym idzie - z kształtowaniem osobowości. Taka perspektywa ujęcia celów pozwala na przywrócenie wysokiej rangi wartościom ogólnoludzkim, odwraca zatem układ wiadomości-umiejętności-postawy na postawy-umiejętności-wiadomości. W nowym układzie celów edukacji odchodzi się od ich hierarchizowania i uznaje się - zgodnie z koncepcją edukacji wielostronnej - brak celów bardziej i mniej ważnych. Takie założenie oznacza akcentowanie podmiotowej (zamiast przedmiotowej) strony osobowości. Podążając tropem reorientacji celów edukacyjnych, napotykamy nowe ujęcie, które jest następujące: rozwój osobowości - kształtowanie postaw, świata wartości 
i światopoglądu - przygotowanie do samorozwoju - wyposażenie w sprawności i wiadomości. Takiemu podejściu przyświecają wartości humanistyczne, nastawione na wychowanie człowieka wyemancypowanego, który samodzielnie myśli i działa, jest wolny, pozbawiony przesądów oraz przygotowany do demokracji, a zatem mającego szansę na świadome funkcjonowanie w świecie nieustających zmian (Kunicka 2005: 18-20).

Istnieje szereg działań, które powinien podejmować nauczyciel, by skutecznie przekazywać wartości etyczne. Homplewicz przedstawia 13 takich działań (Homplewicz 1996: 158-166). Wprowadzenie w świat wartości oznacza, że nauczyciel nie tylko powinien przekazywać informacje o wartościach i umiejętnościach oraz pozwalać na ich intelektualne zrozumienie, ale również pomagać wychowankowi wejść w świat tych wartości poprzez ich akceptację i przyjęcie. Aby mogło jednak nastąpić przyjęcie wartości, które będą kształtować człowieka, jego osobowość i zanim staną się one elementem jego postawy, potrzebne jest zrozumienie wartości, czyli ich treści i znaczeń. Chodzi tu o zrozumienie ich jednocześnie na płaszczyźnie intelektualnej, jak i emocjonalnej. Rolą nauczyciela jest przygotowanie wychowanka na pożądane, świadome i wolne przyjęcie tych wartości, ale zanim to nastąpi, również dostrzeżenie momentu gotowości i otwartości na ich przyjęcie. Akceptacja wartości powinna iść w parze ze zrozumieniem. Rzecz w tym, by wartości były na tyle zrozumiałe, aby uczeń mógł je przyjąć i zaakceptować. Samo bowiem zrozumienie i wiedza nie oznaczają jeszcze przyjęcia i akceptacji. Nauczyciel powinien nie tylko umieć mówić o wartościach, ale także wiedzieć, jak i kiedy to robić. Musi dostosować słowo do sytuacji lub poczekać, aż dana sytuacja się wydarzy. Wtedy słowo wywiera wpływ i można mówić o sytuacji wychowawczej, a więc o adekwatności słów do sytuacji. Wartości etyczne ujawniają swą treść w wydarzających się sytuacjach życiowych. Kiedy słowa nabierają pedagogicznej skuteczności, stają się żywym słowem. Obok adekwatności słów do sytuacji warunkiem skutecznego słowa jest również wierność wypowiadanym słowom, a przez to poglądom i głoszonym wartościom. Wymowa skutecznego słowa może się stać wychowawczym przekazem wartości jedynie wtedy, gdy praktyka życiowa, postawa i wartości nauczyciela są zgodne z tym, co on mówi. 
W tym miejscu pojawia się kolejny warunek skutecznego przekazu wychowawczego - jedność postaw i słów. Wymogiem skutecznego przekazu wartości jest jedność postaw, zachowań i czynów nauczyciela. Głoszone wartości etyczne nabierają bowiem prawdziwej treści i znaczenia jedynie wtedy, gdy są tożsame $z$ wartościami jednostki, która je głosi. Ważny w przekazie wartości jest również kontakt osobowy. Wymagany jest zatem bezpośredni, interpersonalny kontakt między nauczycielem a uczniem, którego bazą jest dialog i rozmowa. Otwartość na prawdę drugiej osoby, zaufanie, życzliwość i serdeczność tego kontaktu mają charakter osobowy, tak jak osobowy jest przekaz i przyjęcie wartości. Taką charakterystyczną cechą kontaktu jest partnerstwo w przekazie wartości. Jak już zostało wcześniej wspomniane, nie liczy się bowiem tylko co i jak się przekazuje, ale także kto to robi i jaki ma stosunek do adresata. W relacji wychowawczej istnieje potrzeba nawiązania partnerstwa opartego na empatii, zaufaniu, szczerości i serdeczności, które będzie otwarciem się na czyjeś przeżycia, świat i prawdę. Dopiero wartości prezentowane jako prawda nauczyciela wyrażająca się w postawie życiowej i przekonaniach stają się wiarygodne dla wychowanka, a tym samym warte przyjęcia jako własne. Autonomia jednostki wobec przekazu wartości oznacza z kolei, że uczeń jest niezależnym podmiotem, a nie tylko obiektem przyjmującym przekazywane wartości. Zatem przekazywane wartości mają dla wychowanka stanowić prawdę, mają być częścią jego własnych przekonań i postawy, a nie jedynie transmisją informacji. W procesie wychowania przekaz wartości jest zawsze dwustronny. W tym układzie nauczyciel i uczeń są zarówno obdarzanymi, jak i obdarzającymi. Wychowawca zyskuje na kontakcie $\mathrm{z}$ wychowankiem, bowiem relacja wychowawcza ma również wpływ na jego życie i osobowość. Przekaz wartości jest procesem dochodzenia, odkrywania, pojmowania i dojrzewania do wartości, nie zaś czynem czy jednorazowym aktem. Warto zaznaczyć, że przekaz wartości jest w zasadzie nieograniczony. Wartości oraz ich treść, rozumienie, proces przekazywania, zakres oraz stopień przyswajania nie mają granic, zatem pożądane jest podnoszenie poziomu doskonalenia człowieczeństwa. Ograniczenie wartości stanowi ograniczenie możliwości człowieka, jest degradacją i redukcją szans. Istnieje potrzeba, by nauczyciel prowadził ucznia ku dojrzewaniu wewnętrznemu, doskonaleniu i budowaniu wartości etycznych. W tym miejscu wyłania się 
zadanie dla nauczyciela, by kształtować $\mathrm{w}$ wychowankach poczucie odpowiedzialności za kształt interioryzowanych przez nich wartości etycznych (Homplewicz 1996: 158-166).

\section{Podsumowanie}

Profesja nauczyciela to zawód, powołanie i służba społeczna, gdzie dobro i prawda są drogowskazem na drodze zawodowej (Janus 2012: 34-35). Nauczyciel bez pasji jest jedynie rzemieślnikiem pracującym według $\mathrm{z}$ góry ustanowionych reguł, robotnikiem tworzącym nakazany produkt, usługę. Trudno zatem, aby ktoś taki stawał się postacią znaczącą, wzorem do naśladowania, idolem dla swoich uczniów. Oni bowiem z jego postaw, zachowań i słów, które wypowiada, potrafią odczytać rozgoryczenie, frustrację, żal czy brak chęci i zainteresowania. Jeżeli w dodatku nauczyciel bardziej troszczy się o swój wizerunek wobec innych nauczycieli lub przełożonych, niż dba o swoich wychowanków i ich rozwój, to buduje negatywny obraz swojego zawodu, tym samym niszcząc jego fundamenty na przyszłość (Śliwerski 2015: 81-83).

O świadomości misji nauczyciela świadczy przede wszystkim jego przekonanie o randze i odpowiedzialności zadań, jakie ma on do wykonania. Ta ranga i odpowiedzialność odnoszą się do procesów wychowania młodego pokolenia związanych $\mathrm{z}$ kształtowaniem właściwych postaw moralnych i obywatelskich, rozwijaniem cech psychofizycznych, rzetelnym wykonywaniem obowiązków oraz dbaniem o bezpieczeństwo dzieci. Równie ważnym elementem misji nauczyciela jest wymiar edukacyjny, czyli przekazywanie wiedzy przedmiotowej (Kawka 1998: 97-101).

Współczesny świat wymaga od nauczycieli, aby byli ludźmi wolnymi, autentycznymi, tolerancyjnymi, szanującymi innych. Wiążą się z tym nieuniknione wyzwania, takie jak brak poczucia bezpieczeństwa, wzrost ryzyka, niepewności, wątpliwości i nieustanne poczucie odpowiedzialności. Nauczyciel powinien zdobywać i umacniać swoją wolność w wyborze i w osiąganiu zamierzonych celów, jednocześnie umacniając swoją autonomiczną pozycję, wystarczająco silną, by móc się przeciwstawiać zewnętrznym naciskom. Powinien umieć odrzucać „nadawaną” rolę zawodową na korzyść roli „zadanej”, która 
pozwala na twórcze poszukiwania, samookreślenie i samostanowienie (Śliwerski 2015: 81-83).

Profesjonalizm nauczyciela wyraża się w wypełnianiu zadań edukacyjnych i wychowawczych w oparciu o swoją wiedzę i umiejętności. Natomiast poczucie misji to wyznacznik, że działa się z pełnym zaangażowaniem dla dobra i rozwoju wychowanka. Funkcjonowanie nauczyciela między misją a profesjonalizmem to nieustanne określanie swojej tożsamości zawodowej w obliczu odpowiedzialności wobec tych dwóch obszarów. Realizowanie zadań zawodowych sprowadza się zatem do umiejętnego oscylowania pomiędzy tymi dwoma uzupełniającymi się aspektami pracy nauczyciela.

\section{Bibliografia}

Dyrda B. (2011). Nauczyciel w roli szkolnego lidera wspierajacego zdolności i uzdolnienia uczniów, [w:] Przywództwo edukacyjne w szkole i jej otoczeniu, red. S.M. Kwiatkowski, J.M. Michalak, I. Nowosad, Warszawa: Wydawnictwo Difin, s. 157-171.

Homplewicz J. (1996). Etyka pedagogiczna, Rzeszów: Wydawnictwo Wyższej Szkoły Pedagogicznej.

Janus A. (2012). Dobre praktyki: Zawód - nauczyciel. Poradnik, Pruszków: Wydawnictwo Naukowe Wyższej Szkoły Kultury Fizycznej i Turystyki im. Haliny Konopackiej.

Kawka Z. (1998). Między misja a frustracją. Spoteczna rola nauczyciela, Eódź: Wydawnictwo Uniwersytetu Eódzkiego.

Kowal S. (2004). Wspótczesne konteksty odpowiedzialności nauczyciela, Kraków: Wydawnictwo Naukowe Akademii Pedagogicznej.

Kunicka M. (2005). Temporalne orientacje teleologiczne nauczycieli, Kraków: Oficyna Wydawnicza „Impuls”.

Kwiatkowska H. (2008). Pedeutologia, Warszawa: Wydawnictwa Akademickie i Profesjonalne.

Łukasik J. (2008). Wspótczesny nauczyciel w środowisku lokalnym. Odgrywanie roli dziatacza spotecznego w środowisku lokalnym w świetle badañ, [w:] $\mathrm{Na}$ uczyciel w śriecie wspótczesnym, red. B. Muchacka, M. Szymański, Kraków: Oficyna Wydawnicza „Impuls”, s. 319-326.

Olejniczak M. (2010). Uwarunkowania rozwoju zawodowego nauczyciela, [w:] Nauczyciel. Rozwój zawodowy i kompetencje, red. E. Przygońska, Toruń: Wydawnictwo Adam Marszałek, s. 49-65.

Sass M. (2011). Nauczyciel, lider - animator wobec lokalnego dziedzictwa kulturowego, [w:] Przywództwo edukacyjne w szkole i jej otoczeniu, red. S.M. Kwiatkowski, J.M. Michalak, I. Nowosad, Warszawa: Wydawnictwo Difin, s. 251-261. 
Śliwerski B. (2015). Nauczyciele w gorsecie MENskich regulacji, [w:] Ucztowieczyć komunikacje. Nauczyciel wobec ucznia w przestrzeni szkolnej, red. H. Kwiatkowska, Kraków: Oficyna Wydawnicza „Impuls”, s. 57-83.

Szempruch J. (2000). Pedagogiczne ksztatcenie nauczycieli wobec reformy edukacji w Polsce, Rzeszów: Wydawnictwo Wyższej Szkoły Pedagogicznej.

Szempruch J. (2013). Pedeutologia. Studium teoretyczno-pragmatyczne, Kraków: Oficyna Wydawnicza „Impuls”.

Szewczyk K. (2013). Wychować cztowieka madrego. Zarys etyki nauczycielskiej, Warszawa: Wydawnictwo Naukowe PWN.

\section{ADRES DO KORESPONDENCJI:}

Mgr Hanna Rugała

Akademia Pomorska w Słupsku

Instytut Pedagogiki

e-mail: hanna.rugala@apsl.edu.pl 